\title{
Sistem Penentuan Lokasi dan Penyimpanan Barang Menggunakan LabVIEW dan Sensor Ultrasonik
}

\author{
Artdhita Fajar Pratiwi*), Sugeng Dwi Riyanto \\ Program Studi Diploma III Teknik Elektronika, Jurusan Teknik Elektronika, Politeknik Negeri Cilacap \\ Jl. Dr. Soetomo No. 1 Sidakaya, Cilacap, Indonesia 53212
}

\begin{abstract}
One of the important aspects in industrial field is a good material handling in logistics. Automated Guided Vehicle (AGV) can be an alternative to making an optimal logistics system. $A$ widely used type of $A G V$ based on its navigation system is line follower robot. This paper explains about applying the line follower robot integrated with LabVIEW to implement ultrasonic sensor as a radar to determine an empty space in logistic storage. The utilization of ultrasonic radar makes the searching process of empty space in the storage faster. Meanwhile, LabVIEW interface is used to help the operator to monitor material handling process. The result of the testing showed that ultrasonic sensor reading in Virtual Instrument LabVIEW has a good precision level when the line follower robot moves in a straight path. The error rate was $6,19 \%$ compared to the real situation.
\end{abstract}

Keywords - Automated Guided Vehicle (AGV); LabVIEW; Ultrasonic

Abstrak - Salah satu aspek penting dalam dunia industri adalah penanganan material yang baik pada bagian logistik. Automated Guided Vehicle (AGV) dapat menjadi alternatif untuk mengoptimalkan sistem logistik tersebut. Jenis AGV yang banyak digunakan berdasarkan jenis navigasinya adalah robot pengikut garis. Pada artikel ini, dipaparkan penggunaan robot pengikut garis yang diintegrasikan dengan LabVIEW untuk mengimplementasikan sensor ultrasonik sebagai radar yang berfungsi menentukan lokasi kosong pada tempat penyimpanan barang. Penggunaan radar ultrasonik membuat pencarian ruang kosong pada tempat penyimpanan menjadi lebih cepat, sedangkan untuk membantu operator dalam memonitor proses penanganan material digunakan antarmuka LabVIEW. Berdasarkan hasil beberapa kali pengujian, pembacaan sensor ultrasonik pada Virtual Instrument LabVIEW memiliki tingkat presisi pembacaan cukup baik pada saat pengikut garis bergerak di lintasan lurus. Adapun kesalahan dalam pembacaan sebesar 6,19\% dibandingkan dengan kondisi sebenarnya.

Kata Kunci - Automated Guided Vehicle (AGV); LabVIEW; Ultrasonik

*) Penulis korespondensi (Artdhita Fajar Pratiwi)

Email: art_dhita@yahoo.com

\section{Pendahuluan}

Penanganan material yang baik pada suatu industri akan memberikan dampak positif yang besar pada industri tersebut, dengan hal itu maka keuntungan industri akan ikut meningkat. Salah satu fokus dalam penanganan material yang baik adalah bagaimana mendistribusikan bahan baku, bahan setengah jadi, atau barang jadi secara efisien dan minim kesalahan. Beberapa metode yang telah digunakan untuk perpindahan material antara lain: konveyor, hand robot, forklift, dan Automated Guided Vehicle (AGV) [1]-[3], tetapi pengembangan pada penanganan material yang berbasis kendaraan bergerak lebih kepada forklift dan AGV. Hal tersebut dikarenakan kebutuhan akan pengerjaan yang fleksibel dengan lokasi kerja yang luas pada satu lantai.

AGV menjadi salah satu pusat perhatian di dunia industri saat dikarenakan beberapa keunggulan yang dimilikinya yaitu konsisten, fleksibilitas, dan otomatisasi dari sistem tersebut. Selain itu, penggunaan AGV dalam dunia industri juga dapat membantu meningkatkan performa bisnis dari segi ekonomi [4] dan peningkatan kapasitas produksi [5]. Meskipun investasi awal cukup besar, tetapi perusahaan dapat melakukan penghematan dari segi tenaga kerja, sehingga untuk jangka panjang lebih menguntungkan. AGV dapat digunakan pada berbagai area kerja, seperti bagian perakitan, penanganan material pada sistem produksi, penanganan material di gudang/logistik, serta penanganan barang di tempat penyimpanan [6].

AGV dapat dibedakan beberapa jenis disesuaikan dengan sistem navigasinya, yaitu berdasarkan jenis lintasannya, kapasitas beban, dan mekanisme pengalamatan pada AGV tersebut [3]. Salah satu jenis AGV yang banyak digunakan dalam industri adalah AGV dengan menggunakan sistem navigasi guide path [3] atau pengikut garis [2]. Pada artikel ini dipaparkan sebuah sistem penanganan material di tempat penyimpanan dengan menggunakan robot pengikut garis yang diintegrasikan dengan antarmuka LabVIEW dan sensor ultrasonik. Algoritma kontrol yang digunakan pada robot pengikut garis agar dapat berjalan sesuai dengan yang diinginkan adalah sistem kontrol PID. Beberapa tahun terakhir ini, pengikut garis dengan menggunakan algoritma lain seperti logika fuzzy juga sudah dikembangkan [7]. 


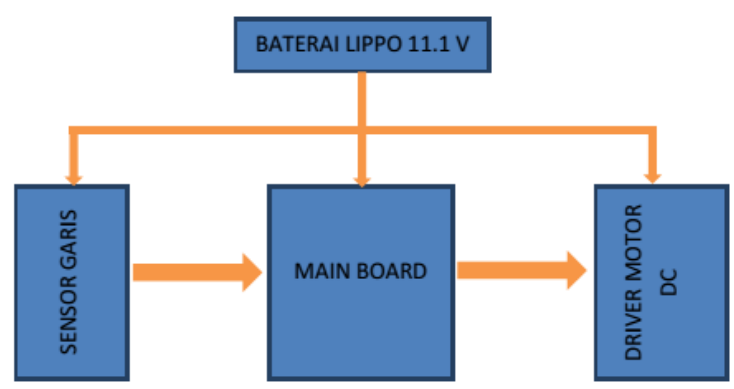

Gambar 1. Blok diagram robot pengikut garis

Sistem ini digunakan untuk mencari lokasi tempat penyimpanan barang yang kosong dengan memanfaatkan sensor ultrasonik yang mampu mendeteksi ada atau tidak adanya penghalang [8]. Operator dapat memonitor kondisi tempat penyimpanan barang melalui antarmuka LabVIEW tanpa harus turun langsung ke lapangan. Pemilihan LabVIEW sebagai antarmuka sistem ini dikarenakan LabVIEW sudah teruji menjadi salah satu perangkat yang sangat berguna untuk mengembangan suatu sistem [9].

\section{Metodologi Penelitian}

Metode penelitian yang digunakan untuk merancang sistem ini, yaitu penelitian eksperimen. Penelitian ini dilakukan dengan beberapa tahapan yang saling berhubungan secara sekuensial linier. Tahapan pertama adalah proses analisis yang dilakukan melalui studi pustaka dan identifikasi masalah. Pada tahap ini dilakukan studi literatur-literatur yang berhubungan dengan proses implementasi sensor ultrasonik dalam menentukan jarak dengan berbagai macam sistem komunikasi dan robot pengikut garis. Tahapan kedua adalah pengembangan sistem, meliputi perancangan robot pengikut garis, perancangan sensor ultrasonik, perancangan bluetooth, perancangan perancangan virtual instrument (VI) LabVIEW, perancangan mekanik dan perancangan sistem keseluruhan.Tahapan ketiga adalah pengujian sistem dengan mengimplementasikan sistem tersebut pada arena yang menyerupai kondisi gudang penyimpanan.

Diagram blok robot pengikut garis terdiri atas baterai Lippo 11,1 V, sensor garis, papan rangkaian utama (mainboard) dan driver motor DC seperti ditunjukkan dalam Gambar 1. Baterai Lippo 11,1 V berfungsi sebagai catu daya untuk menggerakkan robot pengikut garis. Sensor garis berfungsi sebagai masukan untuk mainboard. Mainboard terdiri dari LCD sebagai penampil, penyetel robot dan mikrokontroler sebagai pengatur dari hasil yang diinginkan. Pengaturan pada mikrokontroler juga dilengkapi dengan sistem kontrol PID sehingga robot pengikut garis dapat berjalan sesuai dengan yang diinginkan. Driver motor DC berfungsi sebagai masukan ke motor DC yang merupakan penggerak pada robot pengikut garis.

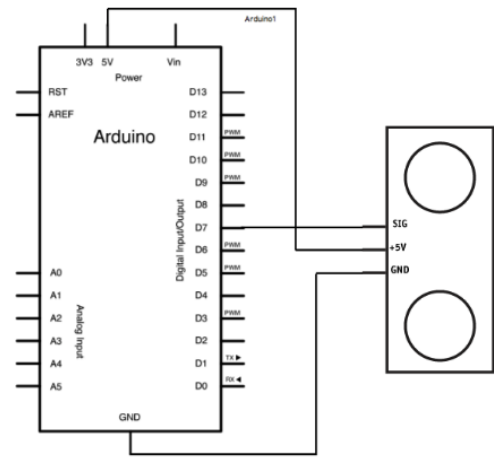

Gambar 2. Rangkaian sensor ultrasonik dengan Arduino

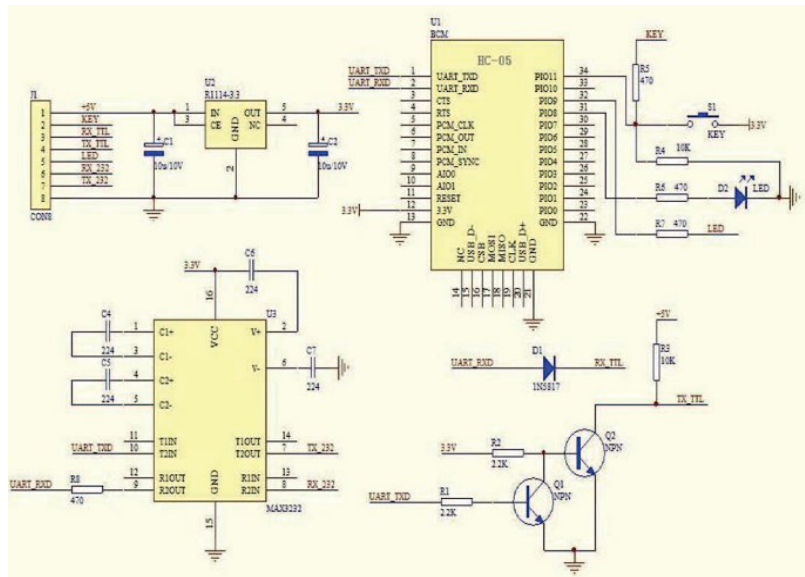

Gambar 3. Rangkaian bluetooth

Sensor ultrasonik yang digunakan adalah sensor ultrasonik ping Parallax. Sensor ultrasonik tersebut dikendalikan melalui sebuah mikrokontroler Arduino. Sensor ultrasonik pada sistem ini berfungsi untuk mendeteksi adanya penghalang, yang diumpamakan sebagai barang/material. Daerah yang tidak terdeteksi oleh sensor ultrasonik dianggap sebagai lokasi penyimpanan yang kosong. Rangkaian sensor ultrasonik tersebut dengan Arduino ditunjukkan pada Gambar 2.

Perangkat bluetooth yang digunakan adalah modul bluetooth HC-05 dengan antarmuka serial. Rangkaian pada perangkat bluetooth dapat dilihat pada Gambar 3. Perangkat bluetooth tersebut dipasang pada Arduino yang dihubungkan dengan perangkat lunak LabVIEW. Bluetooth digunakan untuk mengirimkan data pembacaan jarak dari sensor ultrasonik ke perangkat lunak LabVIEW.

LabVIEW adalah suatu bahasa pemrograman berbasis grafis yang menggunakan icon sebagai ganti bentuk teks untuk menciptakan aplikasi [10]. Tidak seperti bahasa pemrograman berbasis teks yang instruksinya menentukan pelaksanaan program, LabVIEW menggunakan pemrograman dataflow, yang mana alur data menentukan pelaksanaan (execution). Tampilan pada LabVIEW menirukan instrument secara virtual. Pada Gambar 4 ditunjukkan rancangan panel muka virtual instrument (VI) yang akan menampilkan grafik hasil 


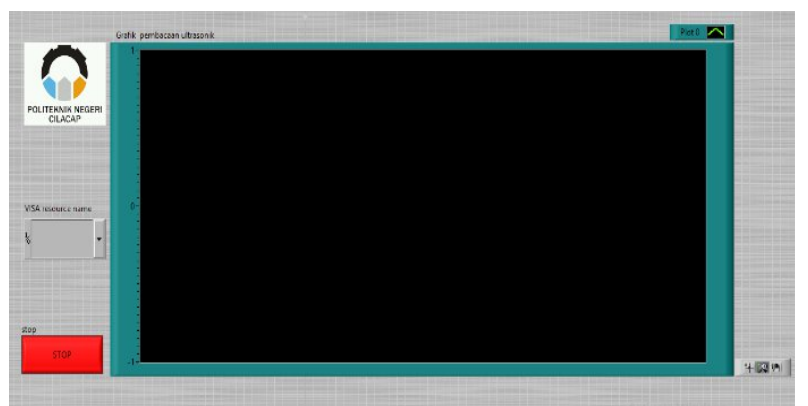

Gambar 4. Tampilan panel muka Virtual Instrument (VI) pada LabVIEW

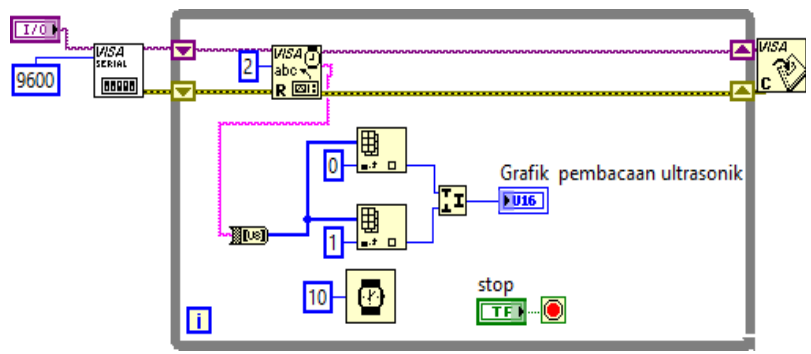

Gambar 5. Diagram blok Virtual Instrument (VI) pada LabVIEW

pembacaan sensor ultrasonik. Hasil pembacaan ultrasonik tersebut akan digunakan untuk mengetahui lokasi penyimpanan barang yang kosong.

Tampilan panel muka VI pada LabVIEW selalu dilengkapi dengan diagram blok yang berisi kode grafis yang mewakili fungsi untuk mengendalikan objek yang dimunculkan pada panel muka VI. Diagram blok untuk fungsi tersebut ditunjukkan pada Gambar 5.

Rancangan mekanik robot pengikut garis ditunjukkan dalam Gambar 6. Gambar tersebut menunjukkan komponen-komponen robot dan tata letaknya, yaitu meliputi sensor garis, mainboard, saklar on/off, port pemrogram, driver motor DC, LCD, motor DC dan baterai Lippo 11.1 V.

Secara keseluruhan, perancangan mekanik pada sistem ini terdiri dari robot pengikut garis yang dilengkapi dengan sensor ultrasonik sebagai pendeteksi keberadaan ruang kosong pada lokasi penyimpanan dan bluetooth sebagai media komunikasi antara sensor ultrasonik dengan perangkat lunak LabVIEW. Pada Gambar 7 ditunjukkan hasil rancangan mekanik untuk sistem secara keseluruhan, yaitu robot pengikut garis yang sudah terpasang sensor ultrasonik dan bluetooth. Sensor ultrasonik akan mendeteksi jarak benda yang ada di sekitarnya dan akan mengirimkan sinyal melalui bluetooth kepada perangkat lunak LabVIEW. Sinyal yang diterima oleh labVIEW menjadi masukan yang akan ditampilkan dalam bentuk grafik pada $V I$.

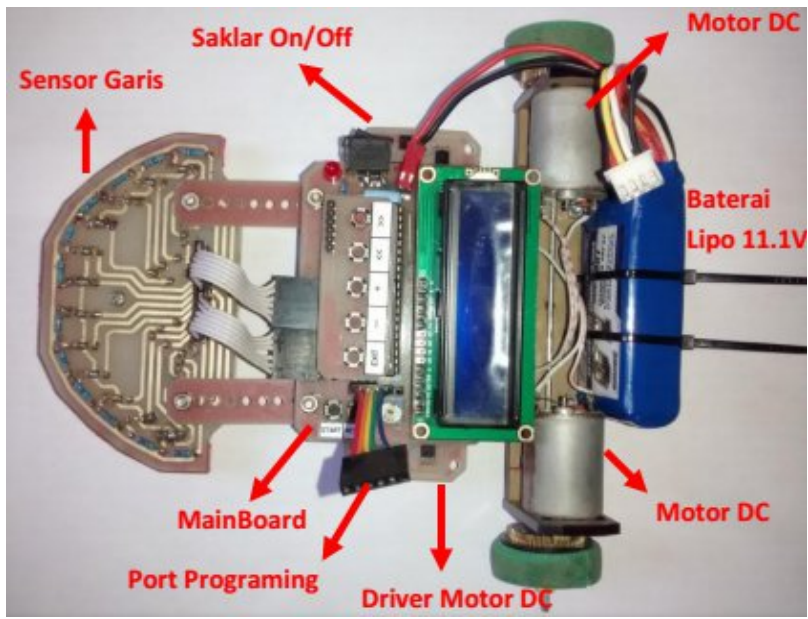

Gambar 6. Perancangan mekanik robot pengikut garis

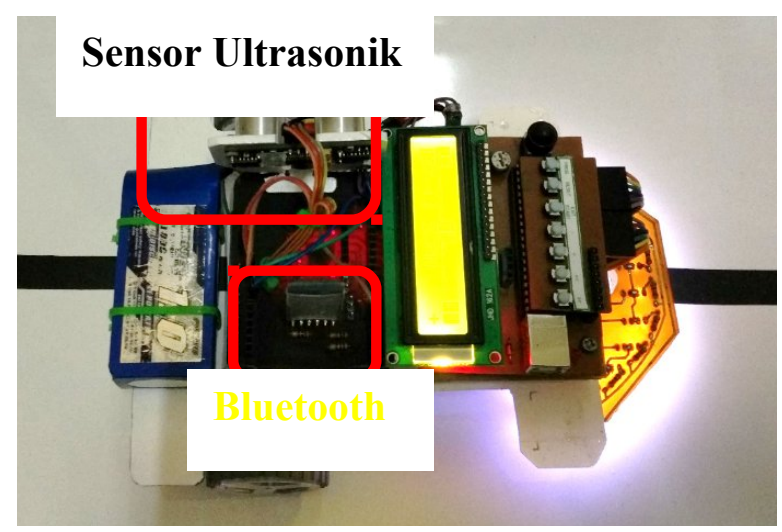

Gambar 7. Perancangan mekanik keseluruhan sistem

Robot pengikut garis ini dirancang sebagai prototipe AGV (Automated Guided Vehicle). Robot pengikut garis tersebut akan bergerak mengelilingi sebuah arena yang dianggap sebagai miniatur tempat penyimpanan sesuai dengan perintah yang diberikan, seperti yang ditunjukkan pada Gambar 8 .

\section{Hasil Dan Pembahasan}

Pengujian robot pengikut garis dilakukan dengan melihat pergerakan robot pada lintasan yang sudah disediakan. Pergerakan tersebut dilihat berdasarkan hasil pembacaan sensor garis dan hasil pengamatan langsung. Gambar 9 adalah lintasan yang dilalui oleh robot pengikut garis. Panjang lintasan keseluruhan adalah $514 \mathrm{~cm}$. Gambar 10 menunjukkan hasil pembacaan LED yang menampilkan pembacaan data digital dari pergerakan robot pengikut garis dan Tabel 1 menampilkan hasil pembacaan sensor garis pada robot pengikut garis. 


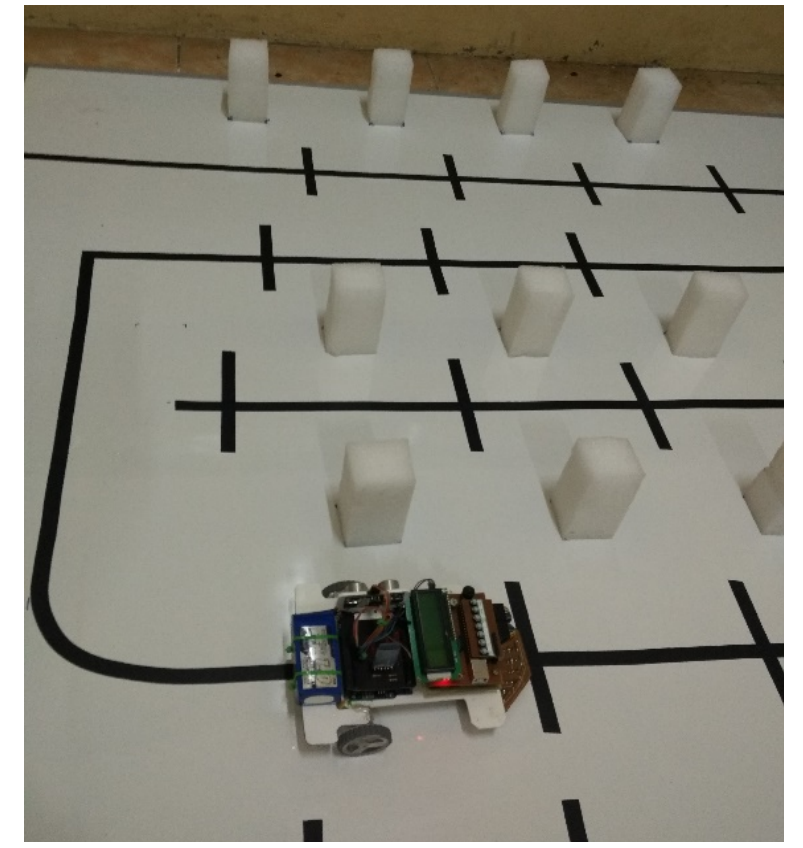

Gambar 8. Arena miniatur tempat penyimpanan barang

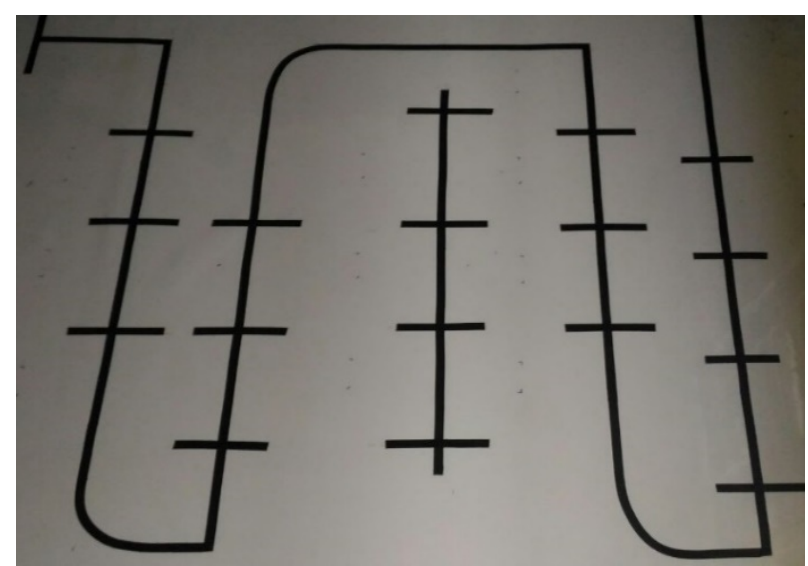

Gambar 9. Lintasan robot pengikut garis

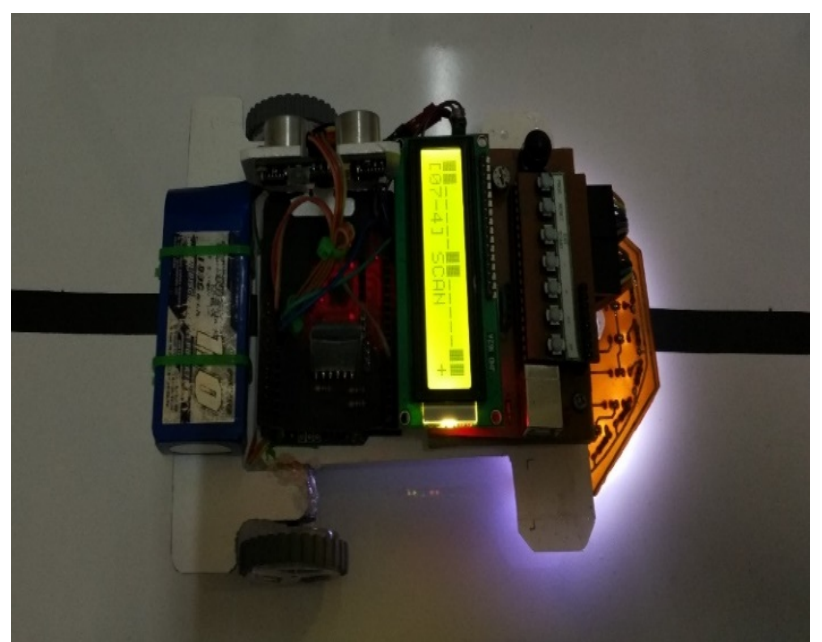

Gambar 10. Hasil pembacaan LED yang ditampilkan dalam data digital
Tabel 1 Hasil pembacaan sensor garis pada robot pengikut garis

\begin{tabular}{|c|c|c|c|c|c|c|c|c|c|c|c|c|c|c|}
\hline \multirow{2}{*}{ No } & \multicolumn{11}{|c|}{ LED pada Sensor Garis } & \multicolumn{3}{|c|}{ Motor } \\
\hline & 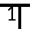 & 2 & & & & & & & 10 & 11 & 12 & KIrI & Kanan & Keterangan \\
\hline 1 & o & & & & & & & & o & 4 & 0 & Mundur & Maju & Belok KIrI \\
\hline 2 & 0 & 0 & 0 & of & & & 0 & & o & of & 0 & Mundur & Maju & Belok KIrI \\
\hline 3 & 0 & 0 & of & 0 & 0 & & of & & o & 0 & 0 & Maju & Maju & Lurus \\
\hline 4 & 0 & 0 & 0 & 0 & & & 0 & & o & of & 0 & Maju & Maju & Lurus \\
\hline 5 & 0 & 하 & & 0 & & & & & 0 & o & 0 & Maju & Maju & Lurus \\
\hline 6 & 0 & 0 & 0 & of & & & & & 0 & 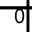 & 0 & Maju & Mundur & Belok Kanan \\
\hline 7 & 0 & 0 & 0 & 0 & of & & & & 0 & of & 0 & Maju & Mundur & Belok Kanan \\
\hline 8 & 0 & 0 & of & of & 0 & & 1 & of & 0 & of & 0 & Maju & Maju & Lurus \\
\hline 91 & 0 & 0 & t & of & of & 1 & 0 & o & 0 & of & 0 & Maju & Maju & Lurus \\
\hline 10 & 0 & 0 & of & of & 1 & 1 & of & 0 & 0 & of & 0 & Maju & Maju & Lurus \\
\hline 11 & 0 & o & 0 & of & 0 & 1 & 0 & 0 & 0 & of & 0 & Maju & Maju & Lurus \\
\hline 12 & 0 & 0 & of & of & $7 t$ & 1 & 0 & 0 & 0 & of & $\overline{0}$ & Maju & Maju & Lurus \\
\hline 13 & 0 & 0 & 0 & of & if & & of & & 0 & of & 0 & Maju & Maju & Lurus \\
\hline 14 & 0 & o & of & of & 011 & & 0 & of & o & of & 0 & Maju & Maju & Lurus \\
\hline
\end{tabular}

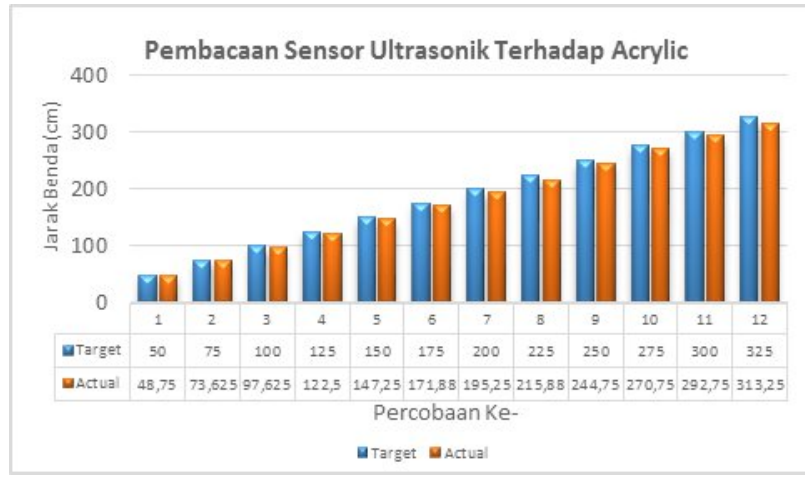

Gambar 11. Hasil pembacaan sensor ultrasonik untuk benda berbahan akrilik

Pada Tabel 1 ditunjukkan 12 LED yang terpasang pada sensor garis. Dari pembacaan 12 LED tersebut, kondisi yang menyatakan bahwa robot pengikut garis dapat berjalan dengan baik adalah apabila lampu 6 dan/atau lampu 7 membaca garis (berlogika 1) ketika robot melewati lintasan yang lurus. Berdasarkan Tabel 1, dapat disimpulkan bahwa robot pengikut garis berhasil bergerak mengikuti lintasan.

Pengujian pada sensor ultrasonik dilakukan melalui beberapa kondisi, yaitu pengujian sensor ultrasonik terhadap jenis benda yang berbeda dan pengujian sensor ultrasonik untuk kondisi bergerak pada lintasan. Kondisi pertama menguji pengaruh jenis benda penghalang terhadap pembacaan sensor ultrasonik. Kondisi kedua menguji kemampuan jarak pembacaan sensor ultrasonik.

Hasil pengujian sensor ultrasonik dengan beberapa jenis benda penghalang diperlihatkan pada Gambar 11 dan Gambar 12. Dari grafik tersebut didapat besar kesalahan yang terjadi untuk benda berbahan akrilik adalah sebesar $2,48 \%$, sedangkan pada benda berbahan foam sebesar $1,40 \%$. 


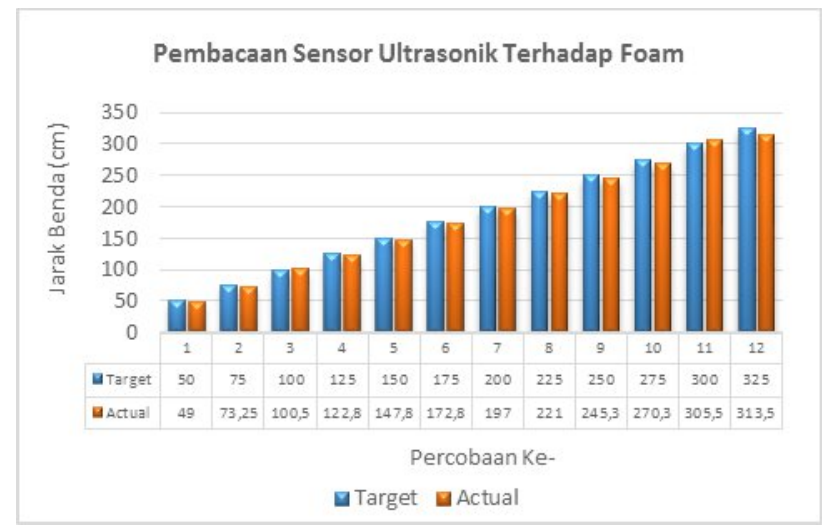

Gambar 12. Hasil pembacaan sensor ultrasonik untuk benda berbahan foam

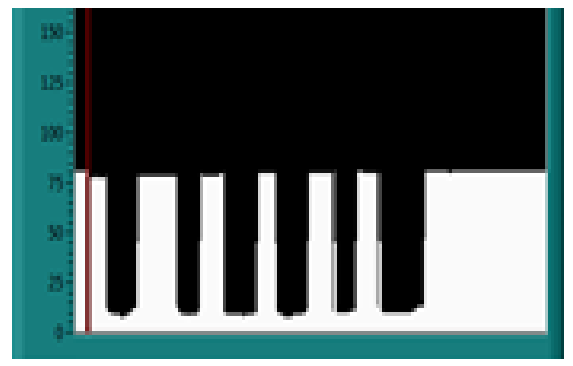

(a)

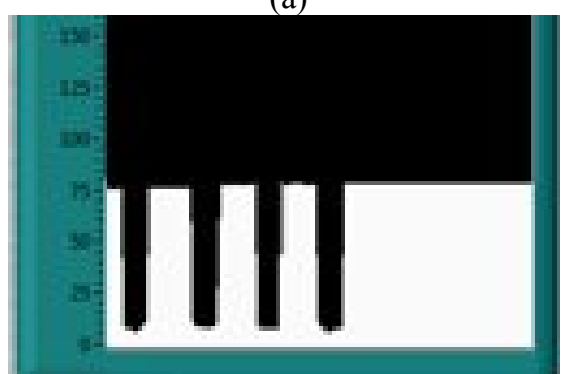

(b)

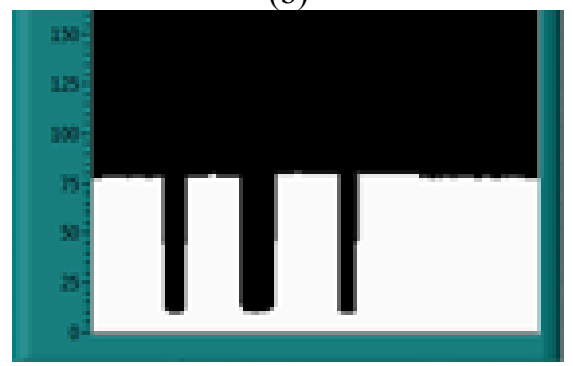

(c)

Gambar 13. Hasil pengujian sensor ultrasonik: (a). jarak antar benda $10 \mathrm{~cm}$; (b). farak antar benda $20 \mathrm{~cm}$; (c). jarak antara benda $25 \mathrm{~cm}$

Hasil ini menunjukkan bahwa jenis benda penghalang juga mempengaruhi sensitivitas pembacaan dari sensor ultrasonik. Selain itu, faktor ketebalan dari benda yang diukur juga menjadi penyebab kurang tepatnya hasil pembacaan. Oleh sebab itu, untuk pengujian pada sistem keseluruhan, dalam penelitian ini menggunakan benda berbahan foam.
Tabel 2 Hasil pengujian daya tembus bluetooth

\begin{tabular}{rlc}
\hline No & Jenis Bahan Penghalang & Proses Koneksi \\
\hline 1 & Akrilik & Berhasil \\
2 & Foam & Berhasil \\
3 & Alumunium & Berhasil \\
4 & Dinding kayu & Berhasil \\
5 & Dinding Beton & Berhasil \\
6 & Kaca & Berhasil \\
\hline
\end{tabular}

Tabel 3 Hasil pengujian koneksi bluetooth

\begin{tabular}{ccc}
\hline No & Jarak (cm) & Proses Koneksi \\
\hline 1 & $50 \mathrm{~cm}$ & Berhasil \\
2 & $100 \mathrm{~cm}$ & Berhasil \\
3 & $200 \mathrm{~cm}$ & Berhasil \\
4 & $300 \mathrm{~cm}$ & Berhasil \\
5 & $400 \mathrm{~cm}$ & Berhasil \\
6 & $500 \mathrm{~cm}$ & Berhasil \\
7 & $600 \mathrm{~cm}$ & Berhasil \\
8 & $700 \mathrm{~cm}$ & Berhasil \\
9 & $800 \mathrm{~cm}$ & Berhasil \\
10 & $900 \mathrm{~cm}$ & Berhasil \\
11 & $930 \mathrm{~cm}$ & Berhasil \\
12 & $1000 \mathrm{~cm}$ & Tidak berhasil \\
\hline
\end{tabular}

Pengujian sensor ultrasonik dalam kondisi bergerak pada lintasan dibedakan berdasarkan jarak antar benda. Kemampuan sensor ultrasonik mendeteksi benda menandakan bahwa sensor ultrasonik dapat bekerja dengan baik. Gambar 13 memperlihatkan hasil pembacaan sensor ultrasonik saat kondisi bergerak pada lintasan. Posisi benda disusun dengan jarak antar benda $10 \mathrm{~cm}, 20$ $\mathrm{cm}$ dan $25 \mathrm{~cm}$. Hasil pembacaan pada antarmuka VI LabVIEW, menunjukkan pada saat sensor ultrasonik membaca benda (ada penghalang), maka VI LabVIEW menunjukkan jarak kurang dari 25 (pada skala). Apabila tidak ada benda, maka pada VI akan menunjukkan jarak yang lebih besar (75 pada skala). Pada pengujian tersebut, benda diletakkan pada jarak $10 \mathrm{~cm}$ dari lintasan robot pengikut garis. Berdasarkan hasil pengujian tersebut, dapat disimpulkan bahwa sensor ultrasonik dapat membaca jarak benda dengan baik meskipun dalam kondisi bergerak pada lintasan.

Pengujian konektivitas bluetooth dilakukan untuk mengetahui kemampuan bluetooth untuk menembus beberapa jenis penghalang dan seberapa jauh jangkauan bluetooth untuk dapat terhubung dengan baik [11]. Hasil pengujian tersebut ditunjukkan pada Tabel 2 tentang hasil pengujian daya tembus bluetooth dan Tabel 3 tentang hasil pengujian koneksi bluetooth dilihat dari jauhnya jarak antara bluetooth dengan perangkat penerima.

Berdasarkan hasil pengujian pada Tabel 2 dan Tabel 3, terlihat bahwa koneksi bluetooth tetap dapat mengirimkan data dengan baik meskipun terhalang dengan berbagai jenis penghalang. Selain itu, koneksi bluetooth mampu mengirimkan data dengan jangkauan 


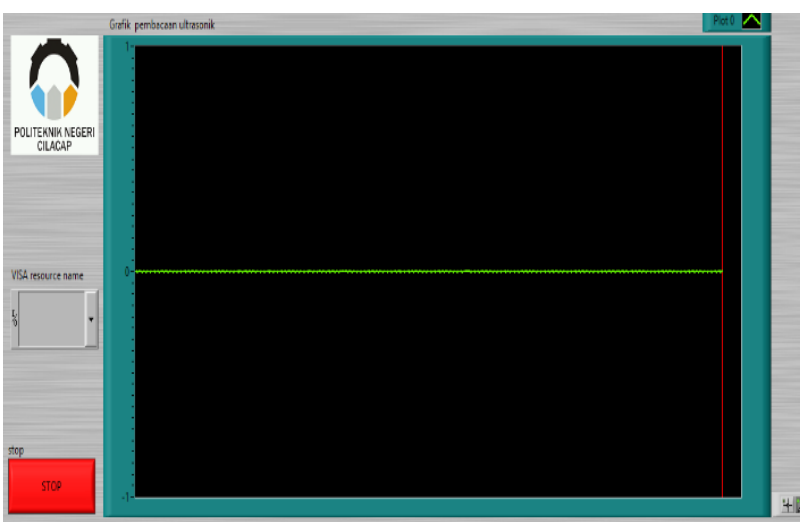

Gambar 14. Hasil pengujian Virtual Instrument LabVIEW

yang cukup jauh, yaitu hingga jarak $930 \mathrm{~cm}$. Oleh sebab itu, komunikasi data dengan menggunakan bluetooth menjadi pilihan dalam proses pengiriman data pada penelitian ini. Bluetooth digunakan untuk mengirimkan data pembacaan jarak dari sensor ultrasonik ke perangkat lunak LabVIEW. LabVIEW akan menampilkan hasil pembacaan sensor ultrasonik tersebut pada VI dalam bentuk grafik. Bluetooth akan mengirimkan data pembacaan sensor ultrasonik secara realtime.

Pengujian VI LabVIEW dilakukan dengan menjalankan program hasil rancangan diagram blok yang ditunjukkan pada Gambar 5. Rancangan tersebut dinyatakan benar, apabila tidak ada kesalahan yang muncul pada diagram blok dan pada VI mampu menampilkan grafik. Berdasarkan hasil pengujian pada Gambar 14, dapat terlihat bahwa VI mampu menampilkan grafik hasil pembacaan. Namun, karena untuk pengujian VI ini tidak dihubungkan langsung dengan sensor ultrasonik, maka hasil keluarannya hanya berupa garis lurus saja.

Secara keseluruhan, sistem ini terdiri dari robot pengikut garis, sensor ultrasonik, bluetooth, dan VI labVIEW. Pengujian sistem secara keseluruhan dilakukan pada sebuah arena yang dilengkapi dengan lintasan robot pengikut garis dan benda-benda yang diposisikan sedemikian rupa. Hasil pengujian yang diambil berupa hasil pembacaan sensor ultrasonik pada VI LabVIEW dalam bentuk grafik. Sistem ini dinyatakan berhasil apabila pada pembacaan sensor ultrasonik mampu mendeteksi jarak ketika melewati benda ataupun pada tempat kosong. Data hasil pengujian yang dilakukan dibedakan menjadi dua, yaitu pada sepenggal lintasan lurus dan pada lintasan penuh.

Perhitungan jarak dari hasil pembacaan pada VI labVIEW menggunakan persamaan (1). Waktu yang dibutuhkan oleh robot pengikut garis untuk menempuh jarak $50 \mathrm{~cm}$ adalah 3,85 detik. Hal ini berarti kecepatan robot pengikut garis adalah $12,99 \mathrm{~cm} / \mathrm{s}$.

$$
s=v x t
$$

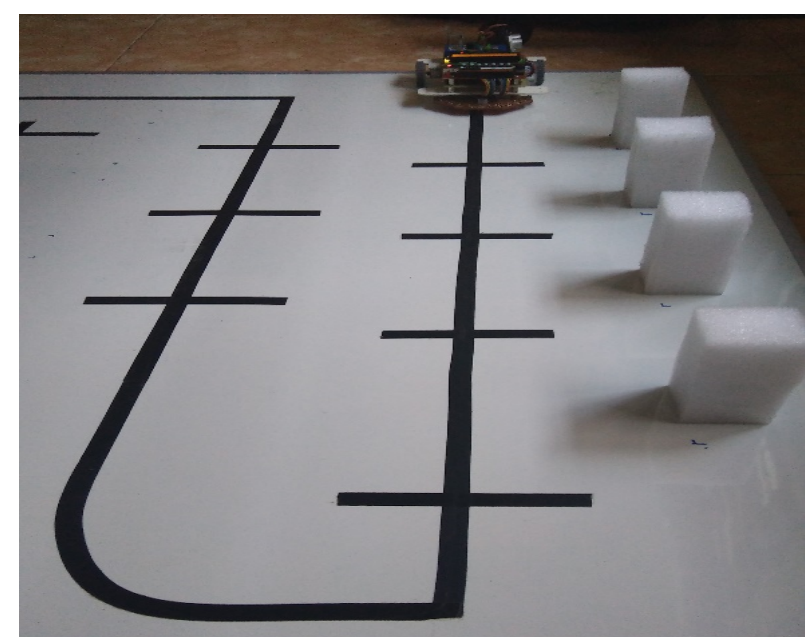

(a)

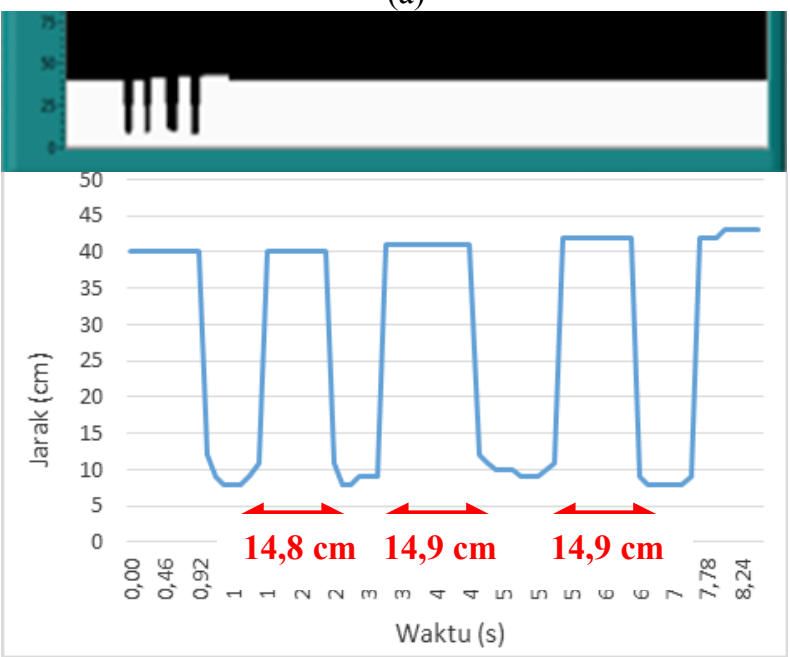

(b)

Gambar 15. Hasil pengujian sistem pada lintasan lurus: (a). kondisi lintasan dan jarak antara benda di arena 14 cm; (b). pembacaan sensor ultrasonik pada VI LabVIEW

$$
\begin{aligned}
\mathrm{v} & =\operatorname{kecepatan}(\mathrm{cm} / \mathrm{s}) \\
\mathrm{t} & =\operatorname{waktu}(\mathrm{s})
\end{aligned}
$$

Berdasarkan hasil pengujian pada lintasan lurus dengan panjang lintasan sejauh $110 \mathrm{~cm}$ dan jarak antara benda $14 \mathrm{~cm}$, diperoleh hasil pembacaan sensor ultrasonik yang cukup presisi (Gambar 15). Pembacaan sensor ultrasonik pada VI LabVIEW menunjukkan bahwa jarak yang terbaca dari perhitungan menggunakan persamaan 1 masih terdapat selisih dengan keadaan sebenarnya. Persentase kesalahan dari pembacaan sebesar 6,19\% atau dengan kata lain tingkat presisi pembacaan sensor ultrasonik adalah 93,81\%.

Berdasarkan hasil pengujian pada sistem secara keseluruhan dengan lintasan penuh dapat dilihat pada Gambar 16. Panjang lintasan penuh adalah $514 \mathrm{~cm}$, dengan beberapa tikungan. Pada lintasan tersebut terdapat tikungan siku $\left(90^{\circ}\right)$ dan tikungan lengkung. Pada gambar

Keterangan : $\mathrm{s}=\operatorname{Jarak}(\mathrm{cm})$ 


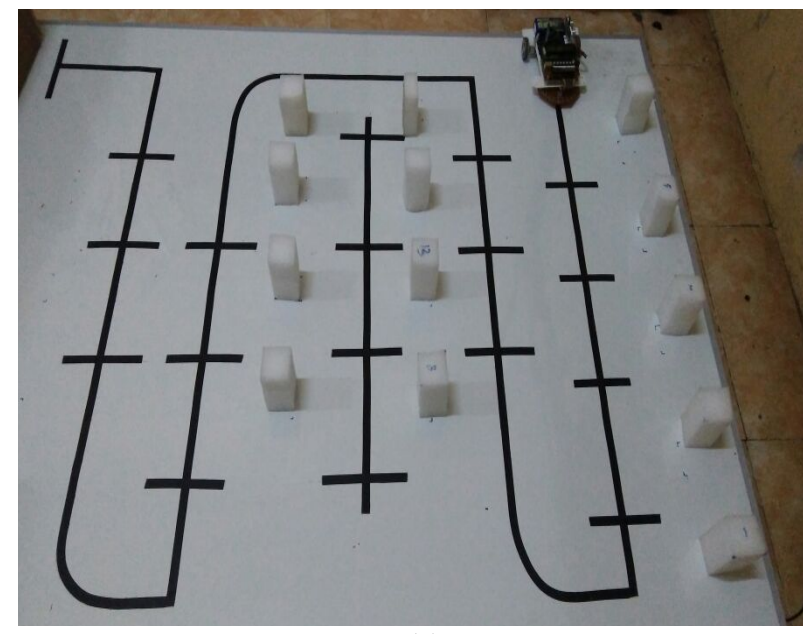

(a)
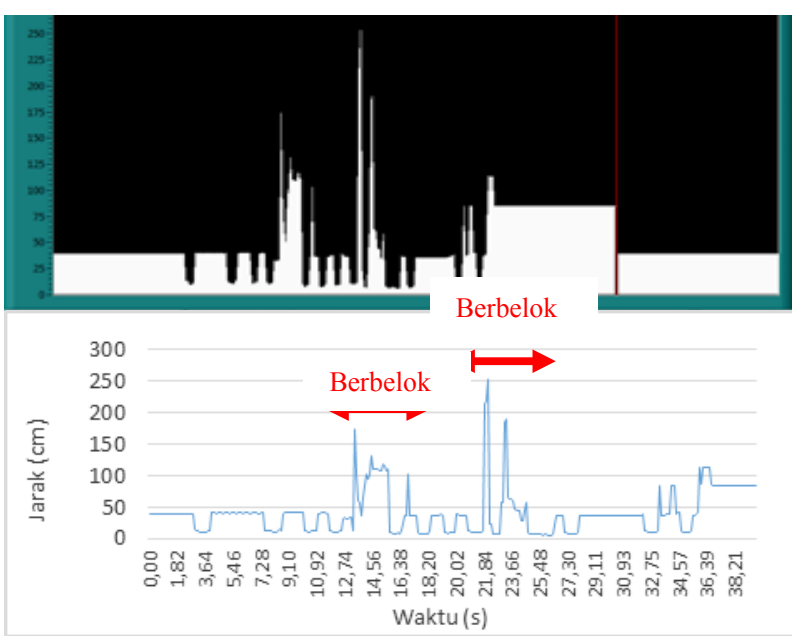

(b)

Gambar 16. Hasil pengujian sistem pada lintasan penuh: (a). kondisi lintasan dan jarak antara benda di arena 14 cm; (b). pembacaan sensor ultrasonik pada VI LabVIEW

tersebut terlihat bahwa pembacaan sensor tidak presisi seperti pada lintasan lurus.

Kemampuan robot pengikut garis untuk dapat berjalan mengikuti lintasan yang ditentukan berhasil dengan baik. Beberapa tikungan patah $\left(90^{\circ}\right)$ yang ada tidak terlalu mempengaruhi performa robot pengikut garis untuk berjalan dengan benar, tetapi sedikit bergetar. Komunikasi bluetooth antara Arduino dan labVIEW juga berhasil dengan baik, meskipun hanya untuk jangkauan yang diberikan. Namun, untuk hasil pembacaan sensor ultrasonik pada VI LabVIEW masih terdapat selisih dengan keadaan sebenarnya.

Pada saat robot pengikut garis bergerak pada lintasan lurus sejauh $110 \mathrm{~cm}$, pembacaan sensor ultrasonik cukup stabil, meskipun masih ada kesalahan pembacaan. Namun, pada saat robot pengikut garis bergerak pada lintasan penuh, sejauh $514 \mathrm{~cm}$, hasil pembacaan sensor ultrasonik menjadi tidak stabil. Pada lintasan lurus pertama, pembacaan sensor ultrasonik masih cukup stabil. Tetapi setelah melewati tikungan, pembacaan sensor ultrasonik menjadi tidak stabil, yaitu dengan munculnya beberapa osilasi yang tidak diharapkan. Selain itu, pembacaan posisi benda dari grafik juga sulit untuk diterjemahkan. Hal ini dapat disebabkan karena getaran yang muncul pada pergerakan robot pengikut garis pada saat bergerak di tikungan, ataupun dikarenakan jauhnya jarak sehingga sensor ultrasonik masih menjangkau benda-benda lain yang ada di sekitarnya.

Prototipe AGV yang menggunakan sistem navigasi pengikut garis ini telah berfungsi dengan baik [2]. Navigasi pengikut garis di AGV ini memberikan opsi lain selain guide path [1],[3]. Dalam melakukan fungsinya sebagai pemindah material, AGV ini dapat mencari lokasi penyimpanan barang yang kosong dengan memanfaatkan sensor ultrasonik untuk mendeteksi ada atau tidaknya penghalang [8]. Antarmuka AGV menggunakan LabView memungkinkan operator untuk memonitor perilaku robot dan kondisi tempat penyimpanan dengan lebih mudah [9]. Algoritma kontrol pengikut garis yang digunakan di robot ini adalah PID, namun dapat dikembangkan dengan algoritma lain seperti Fuzzy [7] untuk menjejak garis yang tidak tegas, misalnya warna yang memudar. Prototipe AGV selanjutnya dapat digunakan untuk memenuhi kebutuhan industri dalam penanganan material [4]-[6].

\section{KESIMPULAN}

Berdasarkan hasil pengujian yang telah dilakukan, dapat disimpulkan bahwa sistem ini berhasil membuat prototipe AGV dengan menggunakan robot pengikut garis yang dilengkapi dengan sensor ultrasonik dan bluetooth sebagai media komunikasi data. Pergerakan robot pengikut garis berhasil mengikuti lintasan yang diberikan. Namun, untuk kecepatan tinggi terjadi getaran ketika melewati tikungan. Pembacaan sensor ultrasonik pada VI LabVIEW mendapatkan hasil yang cukup stabil pada lintasan lurus, tetapi masih bermasalah ketika berjalan pada tikungan. Getaran dari motor penggerak robot pengikut garis cukup mempengaruhi pembacaan sensor ultrasonik. Prototipe AGV ini dapat digunakan sebagai salah satu bagian dalam suatu sistem logistik terintegrasi. Untuk meningkatkan kemampuan sistem, dapat ditambahkan kontroler pada robot pengikut garis agar dapat bergerak secara otomatis.

\section{Daftar Pustaka}

[1] H. Barbera, and M. D. Herrero-Perez., "Autonomous Navigation of An Automated Guided Vehicle in Industrial Environtments", Robotics and ComputerIntegrated Manufacturing, 2010, Elsevier.

[2] A. V. Gaur, and M. S. Pawar, "AGV Based Material Handling System: A Literature Review”, IJRSI, Vol.III, Issue IA, 2016. 
[3] M. Sharma, "Control Classification of Automated Guided Vehicle Systems", in International Journal of Engineering and Advanced Technology (IJEAT), vol. 2, no. 1, 2012.

[4] L. Schulze, S. Behling, and S. Buhrs, "Automated Guided Vehicle Systems: a Driver for Increased Business Performance", in Proceeding of the International MultiConference of Engineers and Computer Scientists (IMECS) Vol II, 2008, Hong Kong.

[5] A.A.B. Sulistyono, and A. Sudiarso, "Simulasi Teknik Penanganan Material Sistem Produksi secara Manual dan Otomatis Berbasis Automated Guided Vehicle (AGV)", in Simposium Nasional RAPI XII, 2013, FT Universitas Muhammadiyah Surakarta.

[6] T. Davich, "Material Handling Solutions: A Look into Automated Robotics", in Wunsch Materials Handling Prize, 2010, University of WisconsinMadison.
[7] A. Mukti, O. D. Nurhayatii, and E. D. Widianto, "Rancang Bangun Sistem Kontrol Robot Line Follower Menggunakan Logika Fuzzy", Jurnal Teknologi dan Sistem Komputer, vol. 3, no. 4. 2015. doi: $\quad$ http://dx.doi.org/10.14710/jtsiskom.3.4. 2015.536-543

[8] J. Park, Y. Je, H. Lee, and W. Moon, "Design of An Ultrasonic Sensor for Measuring Distance and Detecting Obstacles", Ultrasonics, vol. 50, 2010

[9] C. Wagner, S. Armenta, \& B. Lendl, "Developing Automated Analytical Methods for Scientific Environtments using LabVIEW", Talanta, vol. 80, 2010.

[10] W. Larsen and Ronald, "LabVIEW for Engineers", 2011, Prentice Hall. Boston.

[11] Afridanil, Wildian, "Rancang Bangun Sistem Kendali Robot Tangan Menggunakan Bluetooth Berbasis Mikrokontroller Atmega8535”, Jurnal Fisika Unand, vol. 4, 2015. 